Article

\title{
Project-Based Learning as a Method for Interdisciplinary Adaptation to Climate Change-Reda Valley Case Study
}

\author{
Dominika Wróblewska ${ }^{1}$ and Romanika Okraszewska ${ }^{2, *(1)}$ \\ 1 Department of Geodesy, Faculty of Civil and Environmental Engineering, Gdansk University of Technology, \\ 80-233 Gdańsk, Poland; dominika.wroblewska@pg.edu.pl \\ 2 Department of Highway and Transportation Engineering, Faculty of Civil and Environmental Engineering, \\ Gdansk University of Technology, 80-233 Gdańsk, Poland \\ * Correspondence: romanika.okraszewska@pg.edu.pl; Tel.: +48-58-347-27-31
}

Received: 26 April 2020; Accepted: 21 May 2020; Published: 26 May 2020

\begin{abstract}
The challenges of the global labour market require university authorities to extend traditional forms of education into more innovative and effective solutions. Project-based learning (PjBL) is one of highly effective methods for acquiring knowledge and teaching "soft" skills to future employees. This article describes an experimental use of $\mathrm{PjBL}$ at a university with a long history of teaching based on traditional methods-the Gdansk University of Technology. The experiment was conducted in the academic year 2017-2018, in collaboration with the city of Wejherowo. The project's main goal was to solve the city's real problems related to climate change, land development and water management. The project was implemented experimentally as part of two subjects: spatial planning, and monitoring and environmental management to ensure an interdisciplinary approach and cover the scope of the project fully. The results of the experiment confirmed the evidence-based advantages of PjBL. However, several methodological, organisational and technical problems, which need to be resolved before a new edition starts, were encountered during the experimental implementation of the method. The experiment was positively received by students, clients, and tutors. To evaluate the impact of PjBL on spatial planning education, the new edition must include a methodological framework for evaluation.
\end{abstract}

Keywords: project-based learning; transversal skills; civil engineering; spatial planning; adaptation to climate change

\section{Introduction}

Today's industry sets entirely new challenges for engineers. Knowledge and skills are not enough to successfully compete for work. There is evidence to suggest that employers are increasingly prioritising social and emotional skills [1]. Employers look for staff who understand teamwork, discipline, communications, and hard work [2]. Baillie and Fitzgerald [3] state that the skills required for graduates of tomorrow are the skills to analyse, critique and communicate innovative solutions within a team-based work environment. In general, employers report that their main concern is not a shortage of graduates, but the transversal skills of graduates such as communication and problem-solving skills [1].

Due to globalisation of the labour market, universities are expected to align to requirements from the worldwide industry. Governments in Organisation for Economic Cooperation and Development (OECD) countries have identified the development of transversal skills as a priority to face this challenge and therefore undertake interventions (programmes, funds, requirements) to stimulate new 
teaching methods. According to this evidence Poland launched in 2015 its Competencies Development Programme that is aimed at strengthening technical and transversal skills in graduates. The programme places a strong emphasis on cooperation between higher education institutions and employers and includes project-based learning as well [1]. As set out in the national programme, Polish universities are opening new faculties or specializations of study or are improving or developing teaching programmes to adjust graduates' qualifications (technical skills) to the expectations of employers.

The Gdańsk University of Technology (GUT) conducts regular research on the professional careers of graduates, and the results are used to improve the didactic offer and adapt study fields and curriculums to the needs of the labour market. The results prove that over half of GUT students find work immediately after graduation, and their employers value their qualifications highly. However, in-depth interviews confirm the international trend of a deficiency in transversal skills.

In the process of improving graduates' competencies (transversal skills) it is important to select appropriate teaching methods. The adoption of the Bologna Declaration by European universities resulted in the standardisation of academic degrees. It defines the scope of skills, competencies and qualifications to be met by graduates at various levels of education [4]. Yet the new standards adopted in the declaration do not apply to teaching methods, which remain the competency of university authorities and teaching staff. It should be noted here that the teaching methods and content are dependent on teachers' choices and are secondary to the goals and competencies achieved by the student. However, evidence in the didactics literature indicates differences in the effectiveness of different teaching methods (Figure 1). Therefore, a change in teaching methods may improve the effectiveness of learning and expand the list of educational objectives under the condition that they are suitable for the level of education, the subject and the operational objectives [5].

For years teaching at the Faculty of Civil and Environmental Engineering has followed the traditional model of classes divided into lectures, practical work and projects or laboratory work spread out over the semesters. The authors, who have been teaching at GUT for 15-25 years, have mostly adapted to this approach. However, their didactic experience and feedback from the labour market inspired them to go beyond the pattern.

The authors have been trying to implement new teaching methods and a new technology in the didactic process for several years [6-8]. They also noted the inadequacy of traditional teaching methods to spatial planning courses. The general domain of spatial planning is an integration of specialist and general knowledge from different disciplines as well as external stakeholders. The spatial planning process is based on collecting, analysing and processing data from different sources and disciplines. It has to meet changing expectations and laws, and solve actual global and local problems. It involves public participation, discussions and presentation of the progress, which means that the success depends on the "soft skills" of the participants. Courses conducted with traditional methods do not cover all requirements for future engineers. Thus, the authors decided to experimentally introduce the project-based learning $(\mathrm{PjBL}$ ) method. The decision was based on previous international experience of engineering courses using PjBL as described in the literature [9-15]. The inspiration came from the words of Perrenet et al. [16] "that engineering, which tends to be hierarchical, PjBL should be used as a partial solution to develop professional problem-solving skills through the application rather than the acquisition of knowledge." The method was used at master's degree courses because, as required by the Bologna system, students are expected to gain research experience and learn transversal skills.

In the PjBL approach, students are presented with a problem or issue strongly related to the real case study. In the process of exploring and engaging with the subject, students learn the content and transversal skills which are required in teamwork, project work and problem-solving. The method helps to provide specialists with deep professional knowledge and abilities to work for a modern company which appreciates people, its biggest value. It is also effective in introducing environmental knowledge and sustainable approach to land development which in this case refers to climate change issues.

The article describes an experimental application of PjBL at the Gdansk University of Technology's Faculty of Civil and Environmental Engineering under a project for an external client. Due to a wide 
range of client expectations, the decision was taken to combine the spatial planning (SP) course with the monitoring and environmental management (MEM) course, whose skills and abilities are compatible with the SP course and the knowledge supplements the SP.

Section 2 describes the main idea and outline of PjBL and the reasons why PjBL should replace the traditional teaching methods at universities in general and in the case in question. Section 3 presents how course work is organized in the case of the two subjects using PjBL. Section 4 discusses the case study, that is, the topic and scope of the project and how it was conducted within SP and MEM. Section 5 presents experiment results and a stakeholder assessment. Section 6 discusses the issues which emerged during the experiment. Section 7 gives a summary of the experiment, identifies the main advantages and disadvantages in the reality of GUT and offers recommendations for the future.

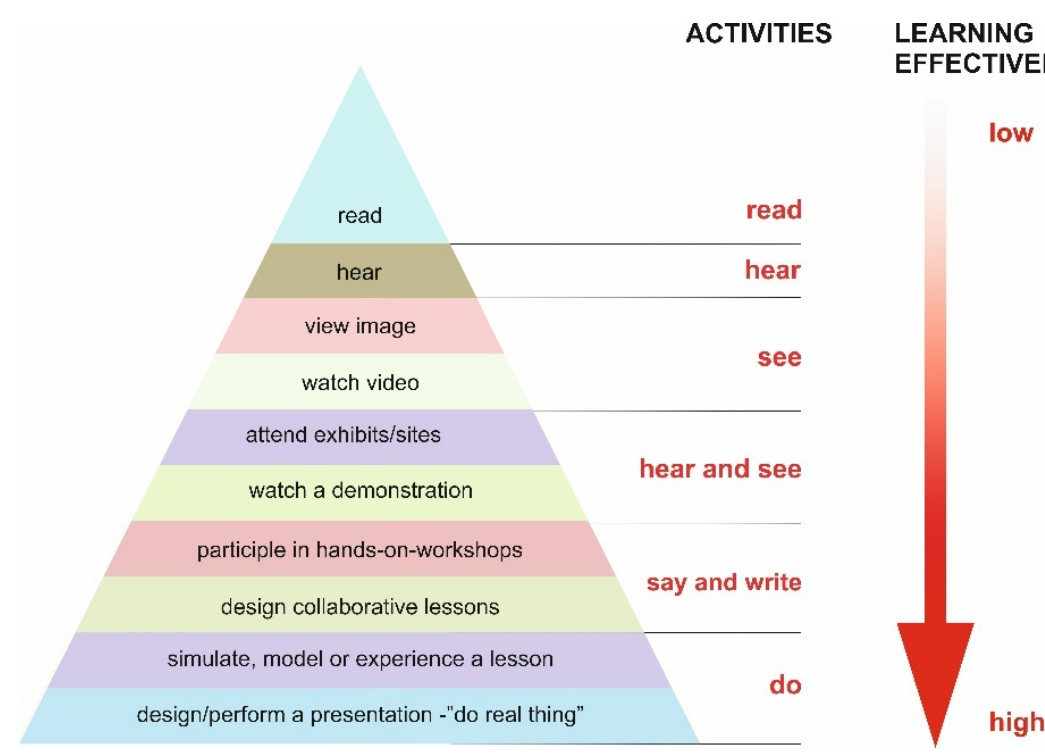

Figure 1. Edgar Dale's pyramid of learning. The relation between the effectiveness of the method and senses used and action undertook. Source: Authors' work based on [17].

\section{The Project-Based Learning Method in Engineering}

Project-based learning (PjBL) has had extensive coverage [9-12,16,18]. The origins of PjBL date back nearly 50 years and go back to Canada's first efforts to deliver problem-based learning (PBL) for a medical course [9]. The method has spread rapidly in medical courses as well as economics, law and psychology [19]. Engineering courses embraced it in the form of the PjBL which differs from PBL in the following ways [9]:

- Time-engineering project tasks usually take longer than problems,

- projects are directed at applications rather than at knowledge acquisition,

- projects are usually run in tandem with traditional lectures,

- time management is a key issue for projects,

- self-direction is stronger in project-based learning as the learning is directed by the problem.

PjBL plays a key role in gaining discipline-specific knowledge, learning technical and transversal skills (taken together, cognitive, social and emotional skills) and stimulating student motivation for creativity $[1,13]$. PjBL is a teaching method where students conduct an activity by following what they agreed to with the lecturer. At first work objectives and methods are set along with completion dates for the whole activity and its phases. There are clear criteria for assessing work stages. Project tasks are usually carried out in a group. When the project is over, the results are presented to a wider audience. As the project progresses, the teacher has the role of coordinator and consultant, and helps with decisions on how to split tasks, controls deadlines and evaluates the results of students' work. 
Projects should be unique and innovative. They are the work of the students who take responsibility for their projects. Even if the project follows a well-known formula, no two activities are ever identical. As project work progresses, students have an opportunity to test many social skills involved in group work such as decision-making, conflict resolution, reaching compromise and sharing roles and tasks. When they work on their own, students learn how to collect information from different sources, and how to select and process it. They also learn how to present the results of their work and how to share them with an audience. Project-based work releases creativity and students learn how to be independent and take responsibility for their project [11]. As a result, the method is more effective than traditional approaches [20].

The main reasons why PjBL was chosen in this case include:

- it develops competencies that are necessary if students want to be effective in the labour market.

- the Bologna system's teaching assessment criteria put emphasis on learning outcomes. This includes graduates' competencies in the area of knowledge, skills (both technical and transversal) and attitudes. Results-oriented teaching attaches more weight to teaching universal and practical skills (such as communications and group work) which are highly appreciated in the labour market and useful throughout the entire professional career.

- it helps to integrate critical issues such as climate change, biodiversity, disaster risk reduction (DRR), and sustainable land development into the curriculum and inspire students to act for sustainability.

\section{Problem Selection}

Spurred by Wejherowo City Hall's interest in gaining a new perspective on Reda Valley redevelopment, the experimental teaching method was put to the test. Two problem areas were defined: Reda riverside land development and solutions to minimise the effects of climate change such as flooding caused by torrential rains in the city which have a direct and indirect impact on Reda Valley. The scope of these two topics is closely interrelated because any plans to introduce retention in the city cannot do without the knowledge of spatial planning and any Reda Valley development should involve retention. Given the wide scope of client expectations, the decision was made to deliver the project as part of two courses. This was to ensure that the client received a comprehensive result. The article presents "Reda Valley", a project implemented by master's degree students in an environmental engineering course at the Faculty of Civil and Environmental Engineering, Gdansk University of Technology. The subjects involved were spatial planning (SP) and monitoring and environmental management (MEM).

As there is evidence that students do not see the relation between knowledge gained from different courses, this case study seemed to be ideal for an innovation using the case of Reda in two courses. It was decided that the Wejherowo City Hall contract should be delivered at the university using project-based learning simultaneously for two subjects in an experimental approach. It was possible as the expected soft skills from both courses were the same and the common main knowledge was water. The authors assumed that as a result the students would:

- verify and integrate knowledge and skills from the two courses by carrying out a real task based on real data to explore how their new knowledge applies to real world situations,

- feel encouraged to search for information and optimal solutions which will shape their critical thinking,

- take an interdisciplinary approach, develop their time management and communications skills and learn to accept views different from their own by working in a group supported by experts,

- learn about the real challenges and processes that are integral to delivering contracts.

The city, on the other hand, was able to work with a consistent project within a single school semester. 


\section{Methodology}

As a consequence, the experiment's main challenge was to plan for flexible hours to work with the project and coordinate the activities between two subjects. Lectures for the two subjects had to be integrated for contents and correlated with the project's successive stages (Figure 2) such as:

- definition of the research problem,

- acquisition of basic knowledge from lectures,

- sourcing the necessary information,

- understanding the methods and tools,

- analysing the existing condition,

- suggesting solutions,

- elaboration of the results,

- public presentation of the results.

The eventual model for a PjBL approach for delivering an external contract under two subjects included shared elements (time for these activities was shared proportionally between the subjects) and those that were specific to one subject only (Figure 2). Shared elements included problem discussion, division of tasks, defining the scope of works, field inventory, workshops and public presentation. To complement the project process, there were traditional lectures, separately for each subject, as well as experts' presentations, invited as consultants. Consultations, initial analyses, posters and presentations were also worked on separately. Delivering some of the stages as a joint activity offered significant benefits:

- working time could be cumulated into blocks which is important for some tasks such as inventory,

- it was possible to exchange knowledge and information and have a joint discussion about proposed changes while ensuring a holistic approach to the topic.

Regardless of the particular teaching method, the main goal of education is to gain new knowledge relevant to the curriculum. In the contract in question, the educational content included an additional focus on designing for climate change and on waterfront development. Thanks to the experimental method, new educational objectives could be added such as:

- learning/improving group work skills, time management, discussion skills and client presentations in the form of posters and short speeches,

- implementing a holistic and interdisciplinary approach to solving engineering problems in the area of urban space development and encouraging students to use knowledge from a number of lecture courses in another setting,

- the connection between graduates' professional attributes and the expectations of their employers. 


\section{Reda Valley Project}

Client guidelines, learning outcomes, curriculum
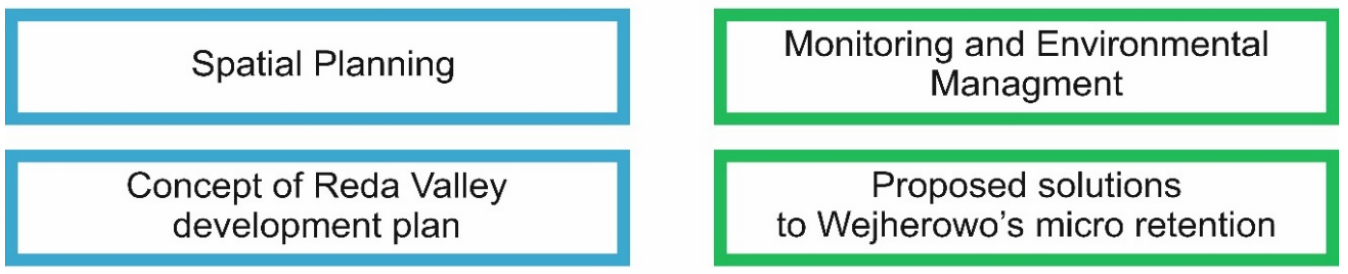

Activities

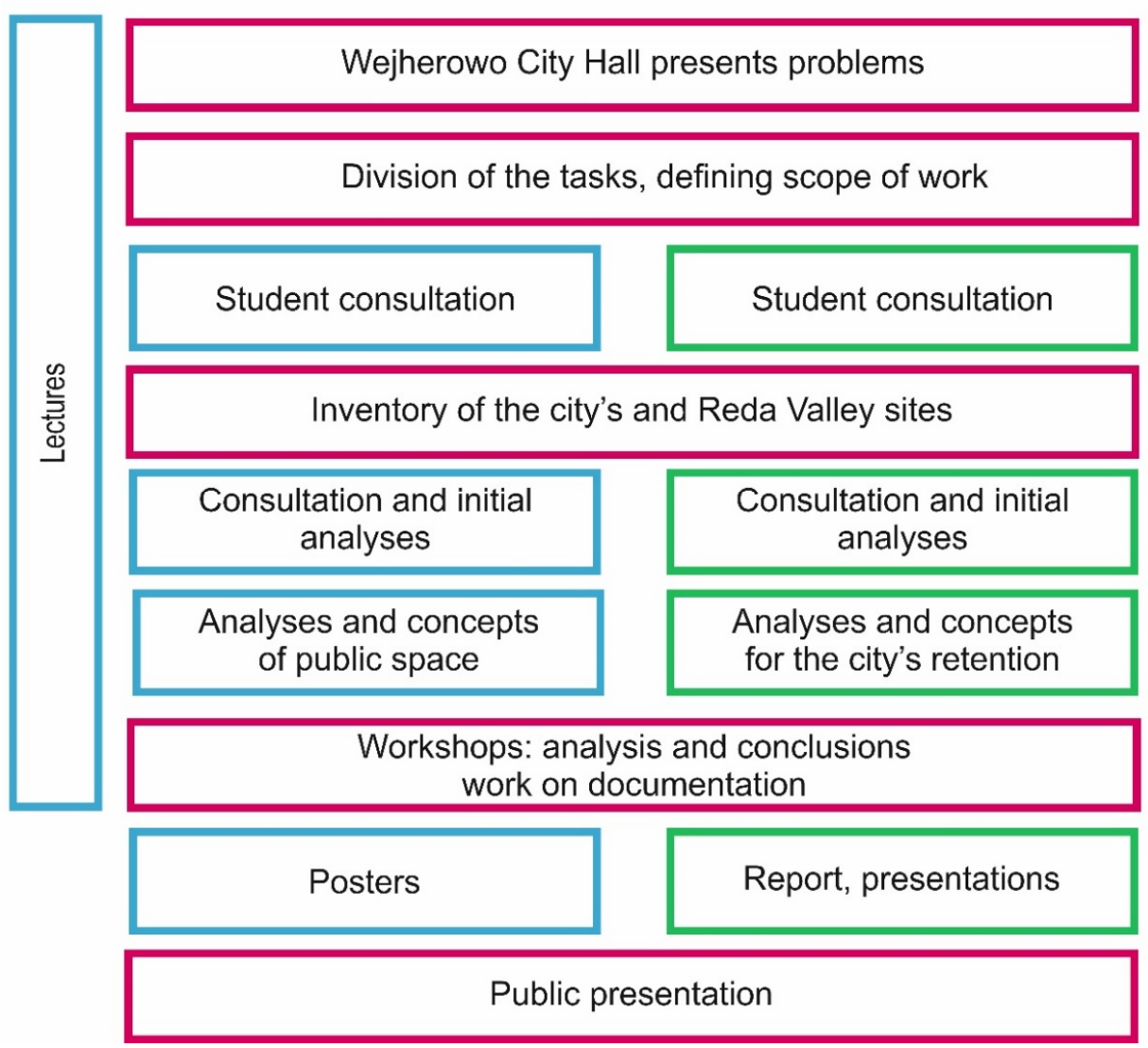

Figure 2. The diagram of applying project-based learning (PjBL)—Reda case study (authors' work).

\section{Case Study-Reda Valley Project, Adapting to Climate Change}

The river Reda is $51 \mathrm{~km}$ long and runs along the Baltic Coast in north Poland, the region of Pomerania. It flows into Puck Bay. Reda's catchment area is mostly within the administrative area of Wejherowo county. The highest population density in the catchment is found in parts of Gdynia, Rumia, Reda and Wejherowo with areas outside the cities featuring low population density. The area's geology includes underthrust and rock fractures.

Areas along the river Reda are home to the town of Wejherowo where it is fed by the river Cedron. The development in the riverside varies. There is a risk of flooding along the Reda and Cedron, a result of short and intense rainfall (Figure 3). Besides, the town struggles with retention capacity and inefficient sewage and rainwater systems. 

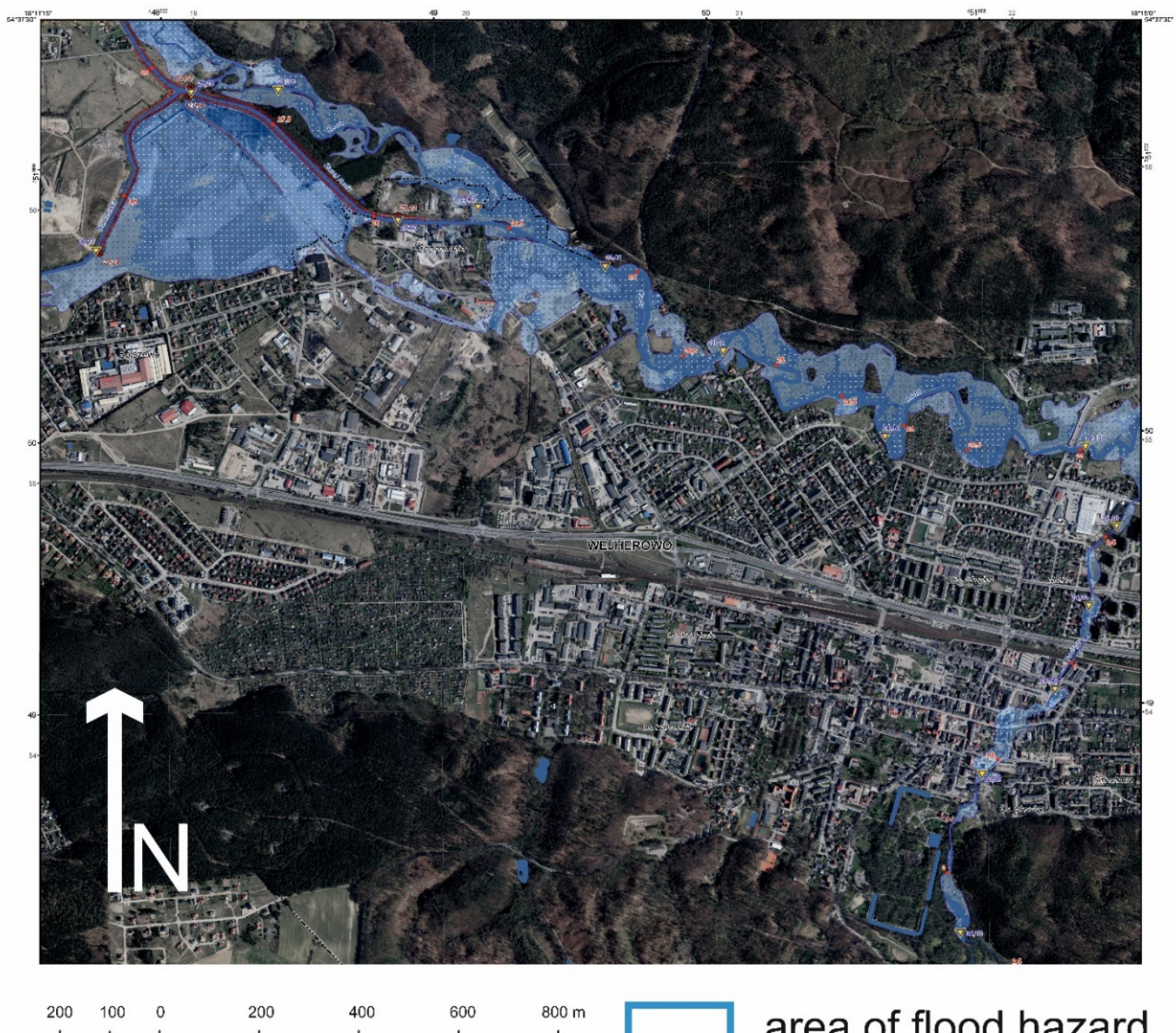

area of flood hazard

Figure 3. Part of the map presenting a flood risk area per 100 years from the rivers Reda and Cedron in Wejherowo. Source: [21].

\section{Project Implementation Stages}

The students were asked to elaborate a Reda riverside development plan as part of their SP course, while solving the risk of flooding and pollution was part of their MEM course.

Because the project covers a vast area, the students were divided into project groups working on the town's specific riverside area. The project objectives were included in instructions, each within the given course (Table 1). The individual stages were integrated into one schedule which included introductory lectures, lectures with specialists, study visits, consultations with course teachers, interdisciplinary workshops and a public presentation of the results (Figure 2).

Project introduction was delivered by Wejherowo's administrative staff with responsibility for urban design, environmental protection and water management. The students were introduced into the city's real problems and were able to understand its needs. The students' first task was to define what needed to be done to deliver the tasks identified in the instructions (Table 1) and assign work to team members. Identifying the scope of necessary data was also included.

For SP purposes students analysed planning documents and carried out a detailed inventory of land and riverside development. They analysed accessibility and resident needs which they collected in interviews. Hazards such as water pollution and noise, and illegal discharges into the Reda and its tributary the Cedron were also identified.

The next step was to study and discuss relevant case studies. Students were also taught about the planning system, planning documents, waterfront development and the relations between water 
management and spatial planning work and about the role played by environmental engineers in creating resident-friendly spaces.

As part of their MEM lectures, the students studied methods of flood control with a focus on nature-based solutions (NBS). They learned about the relation between the built environment, especially public space and water quality, pollution and flooding risk.

Additionally, students had the opportunity to extend their knowledge with interesting articles, and case studies about the topics provided on the platform Moodle.

Once collected, the materials were analysed during one-day workshops. All groups had boards, tables, computers and drawing accessories to use. As a team, the students analysed the data using strengths, weaknesses, opportunities and threats (SWOT) analysis and defined the Reda riverside development patterns. The value added of the workshops was that they involved teachers of both subjects and external experts on transport, environmental engineering, spatial planning, water harvesting and public space development ensuring an interdisciplinary approach. The workshops also provided an opportunity for cooperation between groups working on adjacent areas which some groups undertook. Thanks to this, the designs proposed for riversides were continued in neighbouring areas as well.

The project ended with a public presentation of the results with Wejherowo representatives attending. Each group had five minutes to present its concept and five minutes for questions and answers. Because it was a public presentation the students were able to learn about other designs and give critical feedback on others' analyses, solutions, and clarity of posters and presentation. The latter, in particular, was found to be key before the work was handed over to Wejherowo. Two groups were asked to make improvements to their design.

The project's final assessment combined grades for consistency of solutions, innovation and clarity of presentation of the results including the oral presentation.

Table 1. Reda Valley activities and their scope as part of the spatial planning course and monitoring and environmental management.

\begin{tabular}{|c|c|c|}
\hline & Spatial Planning & $\begin{array}{c}\text { Monitoring and Environmental } \\
\text { Management }\end{array}$ \\
\hline Expected result & Concept of Reda Valley development & $\begin{array}{l}\text { The proposition of solutions to increase } \\
\text { Wejherowo's micro retention capacity }\end{array}$ \\
\hline \multirow{6}{*}{ Main tasks } & Analysis of legal documents & Understanding urban micro retention \\
\hline & $\begin{array}{l}\text { Identifying resident and Wejherowo city } \\
\text { Hall expectations }\end{array}$ & $\begin{array}{l}\text { methods and technologies } \\
\text { Defining the Reda's and Cedron's }\end{array}$ \\
\hline & Inventory of land development & \multirow{5}{*}{$\begin{array}{c}\text { hydrogeological characteristics and flood } \\
\text { risks } \\
\text { Identifying causes of flood risks } \\
\text { Analysis of legal documents related to } \\
\text { project scope } \\
\text { Developing solutions to increase, } \\
\text { Wejherowo's micro retention capacity } \\
\text { multimedia presentation } \\
\text { Final report }\end{array}$} \\
\hline & $\begin{array}{l}\text { Identifying risks to environment } \\
\text { and health }\end{array}$ & \\
\hline & $\begin{array}{l}\text { Analysis of site functions } \\
\text { SWOT analysis }\end{array}$ & \\
\hline & $\begin{array}{c}\text { Developing a concept of Reda riverside } \\
\text { development }\end{array}$ & \\
\hline Expected outcomes & Poster & \\
\hline
\end{tabular}

\section{Results}

Just as with any teaching method, the PjBL method offers both benefits and several challenges for students and teachers alike, forcing everyone to solve problems as they arise in technical, organisational and social areas. Having conducted the analysis of the whole process, the authors identified the elements of the value co-creation process that generated positive (Table 2) and negative outputs (Table 3) of the methodology. 
Table 2. Benefits encountered during the experiment.

- Interactions with real problems and actors. Students communicated that working on the real case and designing the project for the client made the whole process more difficult in terms of the responsibility and made them more motivated to fulfil all expectations and provide a really valuable output. All the groups elaborated the project in time and presented it to the public. The project was developed on two posters, the first one portraying the situation and analysis and the second one showing Methodological the solutions, their location and evaluation, if any (see Supplementary File).

- Interdisciplinary approach to the problem was also found beneficial both for students and tutors. Students could see the relations between different disciplines and approaches, learn how to keep the balance in using their new knowledge and receiving sometimes different and conflicting remarks from experts.

- Development of personal competencies (both teachers and students) and transversal skills (students).

- Strengthen the cooperation with business and city. Discussions with experts and Wejherowo Municipality resulted in new ideas for upcoming projects and new fields of further cooperation.

Table 3. Problems encountered during the experiment.

\begin{tabular}{cll}
\hline Technical & - & $\begin{array}{l}\text { Inappropriate working environment. Lack of technical facilities to carry out group } \\
\text { project work (no proper rooms, lack of equipment such as sockets, wi-fi, sound quality, } \\
\text { etc.); problems with availability and compatibility of geodetic data and software. }\end{array}$ \\
\hline Organisational & $\begin{array}{l}\text { Synchronizing problems of classes for two subjects, coordinating teachers' working } \\
\text { hours, the content of both subjects which had to be presented in the right sequence in } \\
\text { keeping with project stages, external experts and Wejherowo City Hall staff enrolment } \\
\text { in the whole process and especially in workshops and public presentation. }\end{array}$ \\
\hline Methodological & $\begin{array}{l}\text { Teamwork problems. Groups of highly active and motivated students were often very } \\
\text { independent and did not consult anyone especially when preparing the posters; need } \\
\text { for stronger supervision than assumed for some groups, especially on low-activity } \\
\text { students; not enough time for the teams to integrate. } \\
\text { Other. Focusing on organisational issues and monitoring rather than assessing the } \\
\text { process; being overloaded during the whole semester; missing methodological support } \\
\text { for tutors. }\end{array}$ \\
\hline
\end{tabular}

\section{Discussion}

This experimental course was based on assumptions taken from the literature reviews and tutors experience of traditional learning. We have achieved positive results as foreseen based on the literature $[9,13,14,22-26]$. Some results and outcomes, however, were negative or unpredictable.

PjBL had a significantly greater effect than traditional learning [27]. According to [28] the authors implemented all elements required for $\mathrm{PjBL}$, which were: student comprehensive engagement in real-world tasks resulting in a product or presentation to an audience. The students mostly benefitted from the interaction with real problems and the project was delivered for a real client [29]. While this issue was initially reported as very stressful, during the semester it transitioned into high student motivation and engagement. Project experience shows that students are better motivated if their work does not end up "on a shelf" and have a better understanding of the application of their knowledge in practice [26]. Because the project has continuity (activities delivered within a single block), the effect on student engagement was positive. Students willingly engaged in project-based learning and were happy to work on it $[18,30]$.

Chinowsky et al. [31] strongly advocated for the integration of project-based learning concepts throughout the early engineering curriculum. However, in our opinion, this method best suits the masters level at which students already have some field knowledge that they can use and share in an interdisciplinary approach. We assumed that masters course students would be more experienced in teamwork and problem solving using their engineering knowledge and would benefit from a complex, interdisciplinary project better than bachelor level students. 
This engineering course curriculum was designed to develop interdisciplinary-minded practitioners, keen to innovate and solve problems. To achieve the goals, it was important to ensure contact with external experts, new knowledge and ability to use it for problem solving within the project. The students had to present their approach to expert suggestions and opinions, and decide which suggestions should be implemented. They noticed that often it was difficult to acquire consistent information from external experts and tutors as their ideas were created on the basis of different experience. On the one hand students found it confusing; on the other they realized the importance of a good basis of their knowledge to cope with this problem. It was clear that high quality background knowledge from previous courses was beneficial.

Although students may have a less rigorous understanding of engineering fundamentals [26] it is an important argument for us that the results of surveys [1,31] show that those who have experienced $\mathrm{PjBL}$ are better assessed in the market and find a job.

We also noticed the diversity of effects depending on the individual predispositions of students. Rosenfeld and Rosenfeld [23] has distinguished two groups of students, one characterized as "pleasant surprises" (students who perform poorly in conventional classrooms, but who do well in PjBL activities) and "disappointing surprises." Those "disappointing surprises" reported more weaknesses and inconveniences associated with the new mechanism. Regardless of their comments, or rather because of them, we consider it appropriate to confront students with the PjBL method, which simulates conditions similar to real conditions on the labour market and finally helps them to gain new skills.

The satisfying results of the cooperation ensure that partners will also cooperate in future. During the project the meetings involved both scientists and municipality staff and all partners declared their will to continue the cooperation. The municipality has already presented several problems which could be solved with students during masters' thesis work or new student projects.

The research $[25,27,32]$ shows that $\mathrm{PjBL}$ requires both physical and technological support, especially well designed classrooms and information technology. They produced better effects in comparison to traditional learning than seen with PBL without this support. The authors believe that introducing information technology can be crucial for further projects, especially in the form of blended learning supported with the Moodle platform developed at GUT. It is an innovative tool developed for online learning, with all supportive functionalities. Using it during the course can moderate learning in no-distance education and enrich the effectiveness of the course in terms of organisational issues [22], student self-reflection and student-teacher communication [24].

As stated by Gavin [9] dealing with university technical limitations may explain the diversity of $\mathrm{PjBL}$ approaches adopted throughout the world. University-related organisational problems are more likely to be eliminated than external problems so that bigger buffer time should be anticipated in PjBL. The PjBL organization depends on amenities which can be delivered by the university.

In many cases implementation of PjBL needs an individual approach to organisational issues and if the study programme and syllabus are prepared and fixed for traditional learning it is difficult to adopt them to a new solution. According to [33] such problems often appear, and existing syllabuses and schedules must be changed in order to proceed with PjBL and make it suitable for group working activities and cooperation with the client. This course also required changes in traditional schedule and a lot of effort was put into solving structural problems, adjusting weekly schedules to workshops and meetings with external partners. The crucial issues were weather conditions for site visits, available time of the client and experts, available room for the workshops and the possibility of combining the work with standard lectures and consultation hours.

$\mathrm{PjBL}$ requires tutors and students to ensure a bigger involvement and a more active role than in traditional methods [23]. Instead of didactic patterns and schemes which can be repeated year after year without any changes, $\mathrm{PjBL}$ forces changes and new activities. It also comes with a greater responsibility which may push both students and tutors to spend more time on the tasks [33]. During the course, both students and tutors were working under the pressure of time and client expectations which was particularly stressful at the beginning, despite extensive preparations. The students turned out to 
be ambitious and said they were overloaded at the end of the course. However, during the course they undertook activities which could save time. For example, students were very keen to use their knowledge from site visits rather than working additionally with geographic information system (GIS) portals. On the one hand, this approach shows that empirical knowledge and information were more lasting than if sourced from on-line sources. Leaving the numbers aside, this confirms the relation between activity and the ability to memorise information as shown in Figure 1.

It is the university's responsibility to design and implement the environment and support to encourage tutors to undertake these challenges. The essential elements include: appropriate university environment starting from IT solutions and classroom design, modules enabling scheduling PjBL according to studies, and client and project requirements. The didactic assistance of experienced tutors and managers is also important and valuable for innovative and effective didactic $[23,26]$.

As the teams were mostly self-selected, students had positive experiences based on their previous experiences of teamwork in pairs. This is in line with the findings of [29]. However, it was the first time they were working in teams of five or six members. Based on the team work the tutors observed three main problems; (1) some teams were highly active and motivated and did not communicate with tutors during the final stage of elaboration of posters, (2) in some teams, activity was low which slowed down the process at its beginning; and (3) there was no time scheduled for team integration within the project so teams and collaboration were not strong at all project stages at the same level.

While supervising teamwork the authors could observe the process of communication and collaboration. The tutors' supervision had to be conducted at all stages, even though students had competencies in group working. At the beginning of the course they had problems with organisational aspects and doubts if they would manage to finalize the project. Also, some groups at the beginning were not working efficiently and low-activity students had to be motivated. As a result, tutors had to provide supervision and opportunities to express ideas and personal views. Most low-activity students were new to the groups which had worked together before, which suggests that it is not the knowledge but social competencies that are crucial and time for team building is important. This is in line with $[34,35]$ that teamwork takes about half of the learning activity and is important for an effective process.

Evaluation is crucial for both maintaining standards and developing curricula. The didactic process was assessed by the teachers based on their observations, client information and students' impressions. The assessment used qualitative methods which are the most popular (structured or unstructured surveys or participant self-reports), although there were a few using quantitative methods or control groups [23]. Regardless of the method, the results are consistent and compatible with our feelings and observations. Students who participated in project-based learning were generally motivated by it and demonstrated better teamwork and communication skills. They also had a better understanding of the application of their knowledge in practice and the complexities of other issues involved in professional practice.

Assessing the method's effectiveness, just as with many other cases [36], was based on a belief that has mainly been supported by anecdotal evidence and small-scale, evaluative studies that cannot be generalized. From the limited evaluations it is difficult to unambiguously assume whether PjBL is effective. In the quantitative survey conducted at Monash University students noted that "the aims of the new curriculum are taking time to be implemented" and that "learning in the department tends to be mainly project-assisted and partly project-based, rather than problem-based".

The positive aspects noted by students were the use of real-world applications and the development of technical and problem-solving skills. The issues that students perceived to be negative about the project-based learning curriculum were the high time demands of projects and problems with members of groups who did not work as hard as the others. Despite this, in the next edition we plan to apply a systematic approach and assessment methods recommended in the literature [36].

The authors' attitude towards project-based learning was very similar. They tackled the same problems and expectations and noticed mostly the same issues. They found the project very demanding 
in all fields (didactic and organisational) and treated it as a challenge. The additional observed constraint was running PjBL within two synchronized courses.

The final result was positive because the tutors also improved their competencies such as enhanced self-dependence, responsibility for project goals and development, solving unexpected problems, acting intuitively and spontaneously in new situations and satisfaction from tutoring. Their experience was similar to that of other lecturers who reported a positive experience and satisfaction from students' involvement in project-based learning [37].

Even though literature provides descriptions of implementation of PjBL in small groups [31,38], groups of volunteers [31], part of one or more subjects or study fields [10,39], according to the curriculum or outside it [31] there was also a need for more knowledge on PjBL case studies in complex projects. Due to the lack of methodological university support, the authors had to depend on the literature and their own experience. The effectiveness rises when the tutors are supported with methodological instructions and experienced teachers [33] that focus on project-based learning. To solve the problem of missing competencies based on long-term experience [37] some methodical support can be introduced at an institutional level to improve professional competencies of lecturers in proceeding with PjBL as team projects [40].

\section{Conclusions and Recommendation}

Today's problems of climate change and their consequences pose a challenge to engineers of all disciplines. Work on waterfront development in areas with the risk of flooding taps into the knowledge of spatial planning and water and environmental management. By experimentally applying PjBL for two academic courses, the real-life contract could be delivered successfully.

There are more and more examples of replacing the traditional teaching method with the PjBL method as more effective (Figure 1). The results of our experiment extend the examples of successful adoption of the PjBL method into engineering sciences $[9,11,14,18,23,26,30]$. Moreover, according to our best knowledge, this is the first example of its use in spatial planning combined with climate change issues and with interdisciplinary support of environmental engineering, landscape design, biology, ecology and water management disciplines.

The decision to change the teaching method resulted from our own didactic and professional experience and is in line with the Bologna Declaration [4] and labour market requirements [1]. The selection of a specific method was based on pedagogical literature [5] and descriptions of other case studies and literature reviews $[9,12,26,30,37,40-42]$. Our intention was to support engineering science and technical courses by integrating different topics and relating them to industrial practice. Improving student learning and preparing graduates for professional practice is the most frequently repeated and principal argumentation in articles describing the implementation of PBL $[10,12,26,31]$ for using this method.

Developed by the teachers, the method for delivering the contract as part of two academic subjects using PjBL has been successful and will be continued in the next semesters. The methodology of PjBL changes and strongly depends on client and expected results, thus it requires feasibility in organisational issues. It also means that there is no final solution for using PjBL in teaching engineering and its effects also depend on several years of experience and improvements. The methodology is still being developed and improved.

Summarising the experience of the experimental application of $\mathrm{PjBL}$, we can say that:

- PjBL was very well received and embraced by the students,

- the method was instrumental for the timely and comprehensive delivery of the external contract,

- the didactic objectives were met to a wider extent than they were in a traditional setup,

- the PjBL is a dynamic method so it has to be adapted to changing requirements and needs constant supervision. 
The recommendations for the new editions are to:

- develop a faculty-wide procedure for teaching subjects using PjBL to help with a flexible adjustment of hours to project needs and provide space for project work,

- expand the method by adding an element of systematic evaluation of the didactic process. The main objective of the survey is to collect objective feedback on the effectiveness and attractiveness of the method which helps to test teaching for its learning outcomes. This can be done using student or client surveys or other qualitative or quantitative methods known from the literature $[36,43]$. Where surveys are used, they should be conducted twice, before and after the course. This will help to verify the expectations that different groups have on PjBL and how and whether they are met during the course,

- improve group working by team integration, motivation of low-activity students and better work distribution among the team members, supporting flexibility to changeable environment and increasing effectiveness of work organization,

- support teachers with methodological guidelines and workshops on modelling PjBL, group working, collaboration and study organization,

- develop new standards for external client involvement into the teaching process [33],

- implement flexible modules into the syllabus to enable an innovative PjBL approach.

On the basis of the experience the authors believe that the experimental method should be improved and implemented in new semesters. The authors agree with the statement that PjBL is " $(\ldots)$ the best way to satisfy industry needs, without sacrificing knowledge of engineering fundamentals." [26]

Supplementary Materials: The following are available online at http://www.mdpi.com/2071-1050/12/11/4360/s1, Poster1_part_2, Poster2_part_1and2: Examples of projects presented on posters.

Author Contributions: Data curation, D.W. and R.O.; investigation, R.O.; methodology, D.W. and R.O.; supervision, R.O.; visualization, D.W.; writing—original draft, D.W.; writing—review \& editing, R.O. All authors have read and agreed to the published version of the manuscript.

Funding: This research received no external funding.

Conflicts of Interest: The authors declare no conflict of interest.

\section{References}

1. OECD. In-Depth Analysis of the Labour Market Relevance and Outcomes of Higher Education Systems: Analytical Framework and Country Practices Report, Enhancing Higher Education System Performance; OECD: Paris, France, 2017.

2. Tobór-Osadnik, K.; Wyganowska, M. Modern enterprises need engineers of the 21st century-Educational challenges from three points of view (in Polish). Econ. Stud. 2016, 283, 134-146.

3. Baillie, C.; Fitzgerald, G. Motivation and attrition in engineering students. Eur. J. Eng. Educ. 2000, 25, 145-155. [CrossRef]

4. De Gonçalves, M.D.; Pedrosa, I. Bologna declaration and ICT teaching in computer science administration courses context: Reflections for excellency. In Proceedings of the IADIS International Conference on Cognition and Exploratory Learning in Digital Age (CELDA 2006), Barcelona, Spain, 8-10 December 2006; Available online: http://www.iadisportal.org/celda-2006-proceedings (accessed on 19 December 2018).

5. Yakovleva, N.O.; Yakovlev, E.V. Interactive teaching methods in contemporary higher education. Pac. Sci. Rev. 2014, 16, 75-80. [CrossRef]

6. Wróblewska, D.; Okraszewska, R.; Janowski, A. An application of blended and collaborative learning in spatial planning course. In Proceedings of the 6th International Conference on Education and New Learning Technologies, Barcelona, Spain, 7-9 July, 2014; pp. 1164-1171. Available online: https://library.iated.org/view /wroblewska2014ana (accessed on 9 March 2016). 
7. Okraszewska, R.; Dominika, W. The results of the student survey on the Moodle platform at the Faculty of Civil and Environmental Engineering (in Polish). Pismo PG. 2015, 1, 47-48. Available online: http: //pg.edu.pl/documents/1152961/29282631/20150101.pdf (accessed on 9 March 2016).

8. Chróścielewski, J.; Kotarska-Lewandowska, B.; Okraszewska, R. Computer aided teaching of descriptive geometry (in Polish). In Nowoczesne Technologie w Dydaktyce. Wydawnictwo Politechniki Ślaskiej, Kielce; Wydawnictwo Politechniki Świętokrzyskiej: Katowice, Poland, 2011; pp. 84-92. Available online: http://www.pion.pg.gda.pl/publikacja/1613654/2011-komputerowe-wspomaganie-nauczania-geo metrii-wykreslnej (accessed on 9 March 2016).

9. Gavin, K. Case study of a project-based learning course in civil engineering design. Eur. J. Eng. Educ. 2011, 36, 547-558. [CrossRef]

10. Rodríguez, J.; Laverón-Simavilla, A.; del Cura, J.M.; Ezquerro, J.M.; Lapuerta, V.; Cordero-Gracia, M. Project Based Learning experiences in the space engineering education at Technical University of Madrid. Adv. Sp. Res. 2015, 56, 1319-1330. [CrossRef]

11. Palmer, S.; Hall, W. An evaluation of a project-based learning initiative in engineering education. Eur. J. Eng. Educ. 2011, 36, 357-365. [CrossRef]

12. Fernandes, S.R.G. Preparing Graduates for Professional Practice: Findings from a Case Study of Project-based Learning (PBL). Procedia Soc. Behav. Sci. 2014, 139, 219-226. [CrossRef]

13. Lehmann, M.; Christensen, P.; Du, X.; Thrane, M. Problem-oriented and project-based learning (POPBL) as an innovative learning strategy for sustainable development in engineering education. Eur. J. Eng. Educ. 2008, 33, 283-295. [CrossRef]

14. Lacuesta, R.; Palacios, G.; Fernandez, L. Active learning through problem based learning methodology in engineering education. In Proceedings of the 2009 39th IEEE Frontiers in Education Conference, San Antonio, TX, USA, 18-21 October 2009; pp. 1-6. [CrossRef]

15. Graham, R. UK Approaches to Engineering Project-Based Learning, n.d. Available online: http://www.rhgr aham.org/resources/MIT-White-Paper---UK-PjBL-April-2010.pdf (accessed on 19 September 2018).

16. Perrenet, J.C.; Bouhuijs, P.A.J.; Smits, J.G.M.M. The Suitability of Problem-based Learning for Engineering Education: Theory and practice. Teach. High. Educ. 2000, 5, 345-358. [CrossRef]

17. Masters, K. Edgar Dale's Pyramid of Learning in medical education: A literature review. Med. Teach. 2013, 35, e1584-e1593. [CrossRef] [PubMed]

18. Kapusuz, K.Y.; Can, S. A Survey on Lifelong Learning and Project-based Learning among Engineering Students. Procedia Soc. Behav. Sci. 2014, 116, 4187-4192. [CrossRef]

19. Barrett, T. Understanding Problem-Based Learning. In Handbook of Enquiry and Problem Based Learning: Irish Case Studies and International Perspectives, 2nd ed.; Barrett, T., Mac, I., Fallon, L.H., Eds.; Centre for Excellence in Learning and Teaching NUI: Galway, Ireland, 2005; p. 230.

20. Strobel, J.; van Barneveld, A. When is PBL More Effective? A Meta-synthesis of Meta-analyses Comparing PBL to Conventional Classrooms. Interdiscip. J. Probl. Learn. 2009, 3, 1. [CrossRef]

21. Krajowy Zarząd Gospodarki Wodnej, ISOK, (n.d.). Available online: http://mapy.isok.gov.pl/imap (accessed on 10 July 2019).

22. Medeiros, F.; Júnior, P.; Bender, M.; Menegussi, L.; Curcher, M. A blended learning experience applying project-based learning in an interdisciplinary classroom. In Proceedings of the 10th Annual International Conference of Education, Research and Innovation, Seville, Spain, 16-18 November 2017; pp. 8665-8672. [CrossRef]

23. Thomas, J.W. A Review of Research on Project-Based Learning, Learning. 2000. Available online: https://www.semanticscholar.org/paper/A-REVIEW-OF-RESEARCH-ON-PROJECT-BASED-LE ARNING-Thomas/556a3e15b4cfe31588cff520206fff764a413c25 (accessed on 7 May 2020).

24. Ma, H. A study of blended learning strategies for project-based studies. Asia Pac. Inst. Adv. Res. 2016, 2, 50-57. Available online: http://ira.lib.polyu.edu.hk/handle/10397/68269 (accessed on 12 May 2020).

25. Eskrootchi, R.; Oskrochi, G.R. A Study of the Efficacy of Project-based Learning Integrated with Computer-based Simulation-STELLA. J. Educ. Technol. Soc. 2010, 13, 236-245.

26. Mills, J.; Treagust, D. Engineering education-is problem-based or project-based learning the answer? Australas. J. Eng. Educ. 2003. [CrossRef]

27. Chen, C.H.; Yang, Y.C. Revisiting the effects of project-based learning on students' academic achievement: A meta-analysis investigating moderators. Educ. Res. Rev. 2019, 26, 71-81. [CrossRef] 
28. Barron, B.; Darling-Hammond's, L. How can we teach for meaningful learning. In Powerful Learning: What We Know About Teaching for Understanding; The George Lucas Educational Foundation \& Jossey-Bass: San Francisco, CA, USA, 2008; pp. 11-70. Available online: http://eu.wiley.com/WileyCDA/WileyTitle/produ ctCd-0470276673.html (accessed on 13 May 2020).

29. Murgatroyd, S. 'Wicked Problems' and the Work of the School. Eur. J. Educ. 2010, 45, 259-279. [CrossRef]

30. Karim, M.A. Project Based Learning of Environmental Engineering: A Case Study. 2015. Available online: https://www.researchgate.net/publication/279709885 (accessed on 13 May 2020).

31. Chinowsky, P.S.; Brown, H.; Szajnman, A.; Realph, A. Developing knowledge landscapes through project-based learning. J. Prof. Issues Eng. Educ. Pract. 2006, 132, 118-124. [CrossRef]

32. Schmid, R.F.; Bernard, R.M.; Borokhovski, E.; Tamim, R.; Abrami, P.C.; Wade, C.A.; Surkes, M.A.; Lowerison, G. Technology's effect on achievement in higher education: A Stage I meta-analysis of classroom applications. J. Comput. High. Educ. 2009, 21, 95-109. [CrossRef]

33. Ríos, I.D.L.; Cazorla, A.; Díaz-Puente, J.M.; Yagüe, J.L. Project-based learning in engineering higher education: Two decades of teaching competences in real environments. Procedia Soc. Behav. Sci. Elsevier 2010, 2, 1368-1378. [CrossRef]

34. Cinar, Y.; Bilgin, A. Peer assessment for undergraduate teamwork projects in petroleum engineering. Int. J. Eng. Educ. 2011, 27, 310-322. Available online: https://researchers.mq.edu.au/en/publications/peer-assessm ent-for-undergraduate-teamwork-projects-in-petroleum- (accessed on 12 May 2020).

35. Powell, P.C.; Weenk, W. Project-Led Engineering Education; Lemma: Uthrech, The Netherland, 2003.

36. Gibbon, C.; Marcangelo, C. A PBL Evaluation Toolkit: Building the Evidence-Base to Understand Effective Practices. Procedia Soc. Behav. Sci. 2012, 47, 1686-1691. [CrossRef]

37. Lasauskiene, J.; Rauduvaite, A. Project-Based Learning at University: Teaching Experiences of Lecturers. Procedia Soc. Behav. Sci. 2015, 197, 788-792. [CrossRef]

38. Willis, S.C.; Jones, A.; Bundy, C.; Burdett, K.; Whitehouse, C.R.; O'Neill, P.A. Small-group work and assessment in a PBL curriculum: A qualitative and quantitative evaluation of student perceptions of the process of working in small groups and its assessment. Med. Teach. 2002, 24, 495-501. [CrossRef]

39. MacLeod, M.; van der Veen, J.T. Scaffolding interdisciplinary project-based learning: A case study. Eur. J. Eng. Educ. 2019, 1-15. [CrossRef]

40. Kłeczek, R.; Hajdas, M.; Wrona, S. Wicked problems and project-based learning: Value-in-use approach. Int. J. Manag. Educ. 2020, 18, 100324. [CrossRef]

41. Basri, N.E.A.; Zain, S.M.; Jaafar, O.; Basri, H.; Suja, F. Introduction to Environmental Engineering: A Problem-based Learning Approach to Enhance Environmental Awareness among Civil Engineering Students. Procedia Soc. Behav. Sci. 2012, 60,36-41. [CrossRef]

42. Keen, J. A Team Approach to Problem-Based Learning, In AEI 2008; American Society of Civil Engineers: Reston, VA, USA, 2008; pp. 1-10. [CrossRef]

43. Senay, P.; Fila, N.; Nataraja, K. Evaluation of Current Assessment Methods in Engineering Entrepreneurship Education. Adv. Eng. Educ. 2016, 27.

(C) 2020 by the authors. Licensee MDPI, Basel, Switzerland. This article is an open access article distributed under the terms and conditions of the Creative Commons Attribution (CC BY) license (http://creativecommons.org/licenses/by/4.0/). 